\title{
ANALISIS DATA GANGGUAN KERUSAKAN MESIN PRODUKSI MENGGUNAKAN TEKNIK ASSOCIATION RULES
}

\author{
Iveline Anne Marie $^{1)}$, Lukmanul Hakim ${ }^{1)}$, Dedy Sugiarto ${ }^{2)}$, Winnie Septiani ${ }^{1)}$ \\ ${ }^{1)}$ Jurusan Teknik Industri, Fakultas Teknologi Industri, Universitas Trisakti \\ ${ }^{2)}$ Program Studi Sistem Informasi, Fakultas Teknologi Industri, Universitas Trisakti \\ e-mail: iveline.annemarie@ trisakti.ac.id; lukmanul.hakim@trisakti.ac.id; dedy@trisakti.ac.id; \\ winnie_septiani@trisakti.a.id
}

\begin{abstract}
ABSTRAK
Association rules merupakan salah satu teknik data mining yang digunakan untuk menentukan korelasi dari sebuah dataset terkait keputusan yang akan diambil. PT Z adalah perusahaan penghasil komponen otomotif yaitu battery untuk kendaraan bermotor. Gangguan kerusakan mesin produksi pada perusahaan mempengaruhi tercapainya Key Performance Indicator (KPI) Divisi Perawatan pada PT Z. Penelitian ini bertujuan untuk mendapatkan hasil pemetaan dan analisis gangguan kerusakan mesin yang terjadi dengan menggunakan teknik Association Rules sehingga dapat diberikan rekomendasi kegiatan pengendalikan gangguan kerusakan untuk divisi Maintenance. Tahapan penelitian dimulai dengan melakukan kegiatan pengumpulan data kerusakan mesin. Berdasarkan data yang diperoleh dilakukan pengkategorian untuk variabel analisis terpilih. Berikutnya data yang diperoleh akan diolah dengan menggunakan teknik Association Rule untuk melihat pola yang terjadi dengan bantuan packages arules software $R$. Hasil analisis menunjukkan bahwa terdapat hubungan yang kuat antara kerusakan pada shift 2 untuk jenis kerusakan mekanik, serta kerusakan pada shift 3 dengan lama perbaikan sedang dan tingkat resiko yang tinggi memiliki peluang kejadian yang lebih tinggi jika dibandingkan kejadian lainnya. Perusahaan sebaiknya menyediakan kebutuhan staf mekanik, peralatan dan suku cadang yang memadai pada shift 2 dan shift 3 sehingga dapat meminimasi durasi perbaikan mesin dan mencapai target KPI divisi Maintenance.
\end{abstract}

Kata kunci: gangguan, kerusakan mesin, KPI, association rules.

\section{ABSTRACT}

Association Rules is one of the data mining techniques used to determine the correlation of a dataset related to the decisions that will be taken. $P T Z$ is an automotive component producing company, namely a battery for motorized vehicles. The disruption of production machine damage to the company influences the achievement of the Maintenance Division's Key Performance Indicator (KPI) at PT Z. This study aims to obtain the results of mapping and analysis of engine damage that occur using association rules techniques so that recommendations for damage control activities for Maintenance Division can be given. . The stage of the research begins with conducting machine damage data collection activities. Based on the data obtained, it is categorized for selected analysis variables. Next, the data obtained will be processed using the association rule technique to see the patterns that occur with the help of ARules software package $R$. The results of the analysis show that there is a strong relationship between damage to shift 2 for the type of mechanical damage, and damage to shift 3 with the duration of repair and a high level of risk has a higher chance of occurrence compared to other events. The company should provide adequate mechanical staff, equipment and spare parts needs in shift 2 and shift 3 so as to minimize the duration of engine repairs and reach the Maintenance Division KPI target.

Keywords: Disturbance, Machine breakdown, KPI, Association Rules.

\section{PENDAHULUAN}

Industri otomotif merupakan industri yang secara global memiliki karakteristik: membutuhkan ketepatan dan pemanfaatan teknologi modern dengan tingkat integrasi yang tinggi, produksi dengan ratusan supplier dari berbagai tipe industri, kompleksitas tinggi serta kisaran teknologi yang luas. Masa depan industri ini ditentukan oleh kemampuannya untuk beradaptasi dan mengubah kegiatan operasional mereka dengan kerusakan minimum dalam waktu, biaya, sumber daya dan performansi. 
Keberlangsungan industri otomotif dipengaruhi oleh kemampuan untuk bereaksi terhadap ketidakpastian dan dinamika yang terjadi. Terkait dengan sistem produksi, ketidakpastian dikategorikan menjadi dua kelompok: ketidakpastian lingkungan dan ketidakpastian yang terkait dengan proses produksi. Ketidakpastian sistem produksi muncul dalam bentuk gangguan sistem produksi. Itu Adanya gangguan pada sistem produksi menyebabkan inefisiensi dan menghambat pencapaian target KPI pada perusahaan [1].

PT Z adalah perusahaan penghasil komponen otomotif yaitu battery untuk kendaraan bermotor. Terhentinya proses produksi dikarenakan terjadinya gangguan mesin berupa kerusakan komponen mesin produksi pada saat proses produksi terkadang sulit untuk dihindari. Untuk meminimasi terjadinya kerusakan mesin tidaklah mudah, mempertimbangkan bahwa mesin memiliki komponen-komponen yang memiliki umur pakai yang terbatas, sehingga apabila komponen mesin sudah mencapai umur pakainya, komponen tersebut tidak dapat menjalankan fungsinya yang berdampak pada terhentinya proses produksi karena berhentinya mesin produksi. Gangguan kerusakan mesin pada perusahaan mempengaruhi tercapainya Key Performance Indicator (KPI) yang telah ditetapkan perusahaan untuk Divisi Perawatan pada perusahaan tersebut. Divisi Perawatan pada PT Z memiliki KPI untuk Divisi Perawatan Mesin berupa pencapaian target penurunan waktu kerusakan menjadi 108 jam.

Efektifitas dan efisiensi perawatan mesin yang baik akan mempengaruhi waktu ketersediaan produksi dan berujung pada tingkat produksi dan kinerja suatu industri manufaktur. Kerusakan mesin merupakan gangguan produksi yang mempengaruhi efektivitas pabrik. Manajemen bergantung pada ketersediaan kapasitas pabrik yang menjadi dasar perusahaan untuk memperkirakan dalam memenuhi pesanan pelanggan. Perawatan mesin tepat dan strategi perawatan yang tepat diperlukan untuk mencapai target produksi.

Maintenance adalah suatu kegiatan untuk merawat atau menjaga fasilitas atau peralatan pabrik dan mengadakan perbaikan atau penyesuaian atau penggantian yang diperlukan supaya terdapat suatu keadaan operasi produksi yang memuaskan sesuai dengan apa yang direncanakan, maka fasilitas dapat digunakan untuk proses produksi atau sebelum jangka waktu yang direncanakan tercapai [2].

Untuk meminimasi terjadinya gangguan kerusakan mesin, perusahaan dapat mengendalikan gangguan kerusakan mesin dengan cara melakukan perawatan pencegahan atau hanya mampu menekan atau mengantisipasi terjadinya kerusakan dengan menggunakan berbagai strategi dengan memanfaatkan data atau pengetahuan yang dimiliki. Pada penelitian ini dilakukan pemetaan dan analisis gangguan kerusakan mesin yang terjadi dengan menggunakan Metode Association Rules sebagai pendekatan untuk mengendalikan gangguan kerusakan yang terjadi dengan cara melihat pola kerusakan tersebut.

Menurut Margaret dalam Kuswardani et. al. Association Rules merupakan salah satu teknik yang ada didalam data mining yang digunakan untuk menentukan korelasi dari sebuah dataset yang besar. Korelasi yang menarik tentunya akan menghasilkan suatu pola yang unik dan pola inilah yang akan digunakan dalam menentukan keputusan [3]. Berikutnya, penelitian yang dilakukan oleh Hakim dan Fauzy, memanfaatkan Metode Association Rules dalam menentukan pola hubungan kecelakaan lalu lintas pada kendaraan bermotor [4].

\section{TINJAUAN PUSTAKA}

\section{Association Rules}

Association rules merupakan salah satu teknik yang ada di dalam data mining yang digunakan untuk menemukan kombinasi item yang sering terjadi dalam sebuah dataset [5]. Konsep dasar dari association rules mencari pola yang sering muncul atau terjadi di antara banyak transaksi, dimana setiap transaksi terdiri dari beberapa item sehingga teknik ini 
akan mendukung rekomendasi sistem melalui penemuan pola antar item dalam transaksitransaksi yang terjadi [6].

\section{Pembentukan Aturan Assosiatif}

Setelah semua pola frekuensi tinggi ditemukan, barulah dicari aturan assosiatif yang memenuhi syarat minimum untuk nilai confidence. Confidence adalah persentase kejadian dimana jika terdapat kejadian A maka terdapat kejadian B juga sebuah kombinasi item diperoleh dengan rumus berikut [7]:

$$
\begin{aligned}
& \text { Dengan: } \\
& \begin{aligned}
\mathrm{P}(\mathrm{B} \mid \mathrm{A}) & =\text { Probabilitas bersyarat dari kejadian } \mathrm{B} \text { bila kejadian A telah terjadi } \\
\mathrm{P}(\mathrm{A} \cup B) & =\text { Probabilitas kejadian A dan B secara bersamaan } \\
\mathrm{P}(\mathrm{A}) & =\text { Probabilitas kejadian } \mathrm{A}
\end{aligned}
\end{aligned}
$$

Sehingga,$$
\text { Confidence }(\mathrm{A} \rightarrow \mathrm{B})=\mathrm{P}(\mathrm{B} \mid \mathrm{A})
$$$$
=\frac{P(A \cup B)}{P(A)}
$$

Selain kedua parameter di atas yaitu nilai support dan confidence terdapat satu parameter lagi yang dikenal dengan lift ratio. Lift ratio menunjukkan adanya tingkat kekuatan rule atas kejadian aturan asosiasi yang terbentuk. Menurut Zhao, lift ratio adalah confidence dari aturan asosiasi dibagi dengan probabilitas kejadian A dan probabilitas kejadian B yang saling independen atau dinyatakan dengan rumus di bawah ini:

$$
\text { Lift ratio }(\mathrm{A} \rightarrow \mathrm{B})=\frac{\mathrm{P}(\mathrm{A} \cup \mathrm{B})}{\mathrm{P}(\mathrm{A}) \mathrm{P}(\mathrm{B})}
$$

Sehingga,

$$
\begin{aligned}
\text { Lift ratio } & =\frac{\text { confidence }(A=>B)}{P(B)} \\
& =\frac{\text { confidence }(A=>B)}{\text { support } B}
\end{aligned}
$$

Dengan:

$$
\begin{aligned}
& \mathrm{P}(\mathrm{A} \cup B)=\text { Probabilitas kejadian A dan B secara bersamaan } \\
& \mathrm{P}(\mathrm{A}) \quad=\text { Probabilitas kejadian } \mathrm{A} \\
& \mathrm{P}(\mathrm{B}) \quad=\text { Probabilitas kejadian } \mathrm{B}
\end{aligned}
$$

\section{Algoritma Apriori}

Algoritma Apriori merupakan algoritma dasar yang diusulkan oleh Agrawal \& Srikant pada tahun 1994 untuk menentukan frequent itemsets untuk aturan asosiasi. Aturan yang menyatakan asosiasi antara beberapa atribut sering disebut Market Basket Analysis. penting tidaknya suatu asosisi dapat diketahui dengan dua tolok ukur, yaitu: support dan confidence. Support (nilai penunjang) adalah persentase kombinasi item tersebut dalam database, sedangkan confidence (nilai keyakinan) adalah kuatnya hubungan antara-item dalam aturan asosiasi [8].

\section{METODE PENELITIAN}

Penelitian ini menggunakan data gangguan sistem produksi berupa kerusakan mesin yang terjadi pada PT Z untuk bulan Januari - Agustus tahun 2018. Tahapan penelitian dimulai dengan melakukan kegiatan pengumpulan data kerusakan mesin. Berdasarkan data yang diperoleh dilakukan pengkategorian untuk variabel analisis terpilih. Jumlah variabel 
yang digunakan adalah sebanyak lima variabel yaitu lama perbaikan, shift yang digunakan, jenis kerusakan dan tingkat resiko. Berikutnya data yang diperoleh akan diolah dengan menggunakan teknik association rules untuk melihat pola yang terjadi. Pada kasus ini software yang digunakan untuk memudahkan proses analisis data yaitu software R dengan bantuan packages rules untuk mendapatkan pola data.

\section{HASIL DAN PEMBAHASAN}

PT Z menjamin ketersediaan produk-produknya di pasaran untuk menjaga kepuasan pelanggannya. Perusahaan memproduksi dua jenis varian utama battery untuk kendaraan bermotor, yaitu AMB dan MCB. Proses produksi dilakukan dengan menggunakan mesinmesin berikut ini: Cutting Plate, Envloper, Cutting on Strap, Short Tester, Packing, Leg Banding, Polarity Short Tester, Heat Silling Machine dan Auto Pule Barning. Setelah melalui proses-proses diatas terakhir dilakukan pengemasan ke dalam karton box.

Berdasarkan tahapan pengumpulan data, didapatkan data kerusakan mesin yang terjadi antara bulan Januari 2018 sampai dengan tanggal 13 Agustus 2018 sebanyak 314 data kejadian kerusakan yang terjadi dan lama kerusakan 10,570 menit atau 176.17 jam. Tabel 2 berikut ini adalah data kejadian kerusakan mesin dengan lama perbaikan kerusakan yang lama ( $\geq 60$ menit) yang perlu dieksplorasi lebih lanjut oleh divisi maintenance terkait akar penyebabnya serta solusi perbaikannya untuk mengurangi lamanya waktu perbaikan. Mengefektifkan pelaksanaan pendekatan Total Productive Maintenance (TPM) menjadi salah satu solusi bagi Divisi Maintenance PT Z untuk dapat mencapai target KPI nya.

Tabel 2. Data Kerusakan Mesin

\begin{tabular}{|c|c|c|c|c|c|}
\hline No. & Tanggal & Shift & What? & Durasi & $\begin{array}{c}\text { Jenis } \\
\text { Kerusakan }\end{array}$ \\
\hline 1 & 12-Jan-2018 & 3 & As auto conveyor, patah & 600 & Mekanik \\
\hline 2 & 8-Feb-2018 & 2 & Mc 11; motor mesm strip & 150 & Listrik \\
\hline 3 & 19-Feb-2018 & 1 & Mc 24 motor utama suara kasar & 60 & Mekanik \\
\hline 4 & 26-Feb-2018 & 1 & Ampere mould, turun & 60 & Listrik \\
\hline 5 & 28-Feb-2018 & 1 & Pasang heater pot no 9 & 60 & Listrik \\
\hline 6 & 6-Mar-2018 & 1 & Motor utama mc 8 , terbakar & 60 & Listrik \\
\hline 7 & 21-Mar-2018 & 2 & Belt panjang putus mc. No 22 & 60 & Mekanik \\
\hline 8 & 22-Mar-2018 & 3 & mc 22 motor, error & 90 & motor \\
\hline 9 & 4-Apr-2018 & 1 & Cylinder stopper grid, abnormal & 90 & Listrik \\
\hline 10 & 5-Apr-2018 & 3 & Mc. 24 trip terus/start & 60 & Listrik \\
\hline 11 & 6-Apr-2018 & 1 & Motor pompa mc.47, rusak & 90 & Mekanik \\
\hline 12 & 9-Apr-2018 & 3 & Mesin nomer 3 tidak bisa di start & 60 & Listrik \\
\hline 13 & 12-Apr-2018 & 3 & Motor pompa mati & 60 & Listrik \\
\hline 14 & 13-Apr-2018 & 1 & Motor pompa tidak berputar & 60 & Listrik \\
\hline 15 & 16-Apr-2018 & 2 & PLC mati (error) & 360 & Pneumatik \\
\hline 16 & 20-Apr-2018 & 3 & Motor mesin mati & 60 & Mekanik \\
\hline 17 & 20-Apr-2018 & 2 & Motor pompa mc.29 korsleting & 210 & Listrik \\
\hline 18 & 21-Apr-2018 & 3 & Stacker grid error & 60 & Pneumatik \\
\hline 19 & 23-Apr-2018 & 2 & Temperatur POT turun & 60 & Mekanik \\
\hline 20 & 24-Apr-2018 & 1 & Mc.14 pendorong mold, turun & 60 & Mekanik \\
\hline 21 & 5-May-2018 & 2 & Kontaktor pompa timah meledak & 45 & Listrik \\
\hline 22 & 15-May-2018 & 2 & Temperatur POT rendah & 60 & Listrik \\
\hline 23 & 15-May-2018 & 2 & Temperatur POT rendah & 60 & Listrik \\
\hline 24 & 24-May-2018 & 1 & conveyor timah, error & 90 & Listrik \\
\hline 25 & 22-Jun-2018 & 2 & Motor pompa mati & 60 & Listrik \\
\hline 26 & 28-Jun-2018 & 2 & As roll belt pendek patah & 60 & Mekanik \\
\hline 27 & 29-Jun-2018 & 1 & Temp. POT mati (dikarenakan heater korslet) & 60 & Listrik \\
\hline 28 & 13-Jul-2018 & 3 & Temperatur POT turun & 60 & Pneumatik \\
\hline 29 & 16-Jul-2018 & 1 & Motor casting abnormal & 60 & Listrik \\
\hline 30 & 5-Jun-2018 & 2 & Motor tidak mau jalan & 60 & Listrik \\
\hline 31 & 30-Jul-2018 & 1 & Mold tidak tertutup rapat & 90 & Mekanik \\
\hline 32 & 18-Aug-2018 & 2 & As trim des, goyang & 90 & Mekanik \\
\hline 33 & 13-Jul-2018 & 3 & Temperatur POT turun & 60 & Mekanik \\
\hline 34 & 16-Jul-2018 & 1 & Motor casting abnormal & 60 & Listrik \\
\hline
\end{tabular}


Hasil pengolahan data dengan menggunakan software $\mathrm{R}$ dapat diketahui data deskriptif untuk kerusakan yang terjadi adalah sebagai berikut:

1. Jenis kerusakan tertinggi adalah kerusakan mekanik sebanyak 171, listrik sebanyak 104, selanjutnya pneumatik sebanyak 31 kemudian hydraulic dan motor masing masing sebanyak 6 dan 2.

2. Lamanya waktu yang dibutuhkan untuk perbaikan kerusakan kebanyakan adalah singkat, diikuti dengan lama perbaikan sedang dan yang paling sedikit adalah waktu perbaikan yang lama.

3. Jumlah shift yang diterapkan sebanyak 3 shift. Shift yang tertinggi yaitu shift satu dengan jumlah 138, kemudian shift tiga dengan jumlah 92 dan yang terakhir yaitu shift dua dengan jumlah 84 .

4. Tingkat resiko kerusakan yang rendah sebesar 88, tingkat resiko sedang sebesar 183 dan yang terakhir yaitu tinggi adalah sebesar 43 .

Untuk menemukan pola kerusakan yang terjadi pada data kerusakan mesin (breakdown) dilakukan analisis dengan menggunakan Metode Association Rules Algoritma Apriori. Berikut ini adalah contoh perhitungan algoritma association rules dengan menggunakan 5 sampel data.

1. Penentuan Sampel Data Association Rules

Tabel 1. Sampel Data

\begin{tabular}{cccc}
\hline No & $\begin{array}{c}\text { Lama } \\
\text { Perbaikan }\end{array}$ & $\begin{array}{c}\text { Jenis } \\
\text { Kerusakan }\end{array}$ & $\begin{array}{c}\text { Tingkat } \\
\text { Resiko }\end{array}$ \\
\hline 1 & Lama & Hydraulic & Rendah \\
2 & Singkat & Listrik & Tinggi \\
3 & Lama & Listrik & Tinggi \\
4 & Lama & Hydraulic & Rendah \\
5 & Singkat & Hydraulic & Tinggi \\
\hline
\end{tabular}

2. Membuat data pada tabel di atas menjadi matriks bilangan biner yaitu jika 1 maka menandakan bahwa proses tersebut terjadi dan jika 0 maka proses tersebut tidak terjadi.

Tabel 2 berikut ini menunjukkan matriks biner untuk data sampel pada Tabel 1.

Tabel 2. Penentuan Matriks Biner Data Sampel

\begin{tabular}{ccccccc}
\hline No & Lama & Singkat & Hydraulic & Listrik & Tinggi & Rendah \\
\hline 1 & 1 & 0 & 1 & 0 & 0 & 1 \\
2 & 0 & 1 & 0 & 1 & 1 & 0 \\
3 & 1 & 0 & 0 & 1 & 1 & 0 \\
4 & 1 & 0 & 1 & 0 & 0 & 1 \\
5 & 0 & 1 & 1 & 0 & 1 & 0 \\
\hline Total & 3 & 2 & 3 & 2 & 3 & 2 \\
\hline
\end{tabular}

3. Menentukan total frekuensi item set serta jumlah item set yang digunakan. Total frekuensi item set sebanyak 2 dengan item set sebanyak 3.

Tabel 3. berikut ini menunjukkan beberapa kombinasi data sampel yang terbentuk.

Tabel 3. Kombinasi Data Sampel

\begin{tabular}{cccc}
\hline \multicolumn{4}{c}{ Kombinasi 1 } \\
\hline Lama & Hydraulic & Rendah & $\mathrm{x}$ \\
\hline 1 & 1 & 1 & 1 \\
0 & 0 & 0 & 0 \\
1 & 0 & 0 & 0 \\
1 & 1 & 1 & 1 \\
0 & 1 & 0 & 0 \\
\hline \multicolumn{5}{c}{}
\end{tabular}

\begin{tabular}{cccc}
\hline \multicolumn{4}{c}{ Kombinasi 2 } \\
\hline Lama & Listrik & Rendah & $\mathrm{x}$ \\
\hline 1 & 0 & 1 & 0 \\
0 & 1 & 0 & 0 \\
1 & 1 & 0 & 0 \\
1 & 0 & 1 & 0 \\
0 & 0 & & 0 \\
\hline \multicolumn{4}{c}{}
\end{tabular}


Lanjutan Tabel 3. Kombinasi Data Sampel

\begin{tabular}{|c|c|c|c|}
\hline \multicolumn{4}{|c|}{ Kombinasi 3} \\
\hline Lama & Hydraulic & Tinggi & $\mathrm{x}$ \\
\hline 1 & 1 & 0 & 0 \\
\hline 0 & 0 & 1 & 0 \\
\hline 1 & 0 & 1 & 0 \\
\hline 1 & 1 & 0 & 0 \\
\hline 0 & 1 & 1 & 0 \\
\hline & $\Sigma$ & & 0 \\
\hline \multicolumn{4}{|c|}{ Kombinasi 5} \\
\hline Singkat & Hydraulic & Rendah & $\mathrm{X}$ \\
\hline 0 & 1 & 1 & 0 \\
\hline 1 & 0 & 0 & 0 \\
\hline 0 & 0 & 0 & 0 \\
\hline 0 & 1 & 1 & 1 \\
\hline 1 & 1 & 0 & 0 \\
\hline & $\Sigma$ & & 1 \\
\hline \multicolumn{4}{|c|}{ Kombinasi 7} \\
\hline Singkat & Hydraulic & Tinggi & $\mathrm{X}$ \\
\hline 0 & 1 & 0 & 0 \\
\hline 1 & 0 & 1 & 0 \\
\hline 0 & 0 & 1 & 0 \\
\hline 0 & 1 & 0 & 0 \\
\hline 1 & 1 & 1 & 1 \\
\hline & $\Sigma$ & & 1 \\
\hline
\end{tabular}

\begin{tabular}{|c|c|c|c|}
\hline \multicolumn{4}{|c|}{ Kombinasi 4} \\
\hline Lama & Listrik & Tinggi & $\mathrm{x}$ \\
\hline 1 & 0 & 0 & 0 \\
\hline 0 & 1 & 1 & 0 \\
\hline 1 & 1 & 1 & 1 \\
\hline 1 & 0 & 0 & 0 \\
\hline 0 & 0 & 1 & 0 \\
\hline & & $\Sigma$ & 1 \\
\hline \multicolumn{4}{|c|}{ Kombinasi 6} \\
\hline Singkat & Listrik & Rendah & $\mathrm{x}$ \\
\hline 0 & 0 & 1 & 0 \\
\hline 1 & 1 & 0 & 0 \\
\hline 0 & 1 & 0 & 0 \\
\hline 0 & 0 & 1 & 0 \\
\hline 1 & 0 & 0 & 0 \\
\hline & & $\Sigma$ & 0 \\
\hline \multicolumn{4}{|c|}{ Kombinasi 8} \\
\hline Singkat & Listrik & Tinggi & $\mathrm{x}$ \\
\hline 0 & 0 & 0 & 0 \\
\hline 1 & 1 & 1 & 1 \\
\hline 0 & 1 & 1 & 0 \\
\hline 0 & 0 & 0 & 0 \\
\hline \multirow[t]{2}{*}{1} & 0 & 1 & \\
\hline & & $\Sigma$ & 1 \\
\hline
\end{tabular}

Pada kolom $\mathrm{X}$ angka 1 artinya item-item yang terjadi adalah bersamaan, sedangkan 0 berarti tidak ada item yang terjadi bersamaan atau tidak terjadi kejadian. $\Sigma$ melambangkan total frekuensi item set. Total frekuensi item set harus lebih besar atau sama dengan total frekuensi item set yang telah ditentukan. Frekuensi item set yang ditentukan di atas yaitu sebanyak 2 item set, dan jika kurang dari 2 maka aturan tersebut tidak dipakai. Pada tabeltabel di atas didapatkan 1 kombinasi yang nilai frekuensi item set sama dengan total frekuensi item set yang ditentukan yaitu terdapat pada kombinasi 1 .

4. Langkah selanjutnya mengambil kombinasi yang memenuhi syarat yang telah ditentukan yaitu dengan total frekuensi item set 2 dan item set yang digunakan sebanyak 3. Kombinasi yang memenuhi syarat terdapat pada kombinasi 1 dengan total frekuensi item set sebanyak 2 sesuai dengan data pada Tabel 3 untuk kombinasi 1. Aturan yang terbentuk adalah \{Lama, Hydraulic, Rendah\} atau kerusakan dengan lama perbaikan lama untuk jenis kerusakan hydraulic dan tingkat risiko rendah.

5. Rule yang digunakan adalah if $x$ then $\mathrm{y}$, dimana $x$ adalah antecendent dan y adalah consequent. Berdasarkan rule tersebut, maka dibutuhkan 2 buah item set yang mana salah satunya sebagai antecedent dan sisanya sebagai consequent.

Data pada Tabel 4 menunjukkan data if then serta nilai support, confidence dan lift berdasarkan data sampel.

Tabel 4. Aturan Berdasarkan Data Sampel

\begin{tabular}{|c|c|c|c|c|}
\hline No & $\begin{array}{c}\text { If Antecedent then } \\
\text { Consequent }\end{array}$ & Support & Confidence & Lift \\
\hline 1 & $\begin{array}{l}\text { Jika waktu perbaikan lama } \\
\text { dan kerusakan Hydraulic } \\
\text { maka Tingkat resikonya } \\
\text { rendah. }\end{array}$ & $\begin{array}{l}\text { \{Total kejadian terjadi } \\
\text { secara bersamaan/Total } \\
\text { data }\}=\{2 / 5=0.4\}\end{array}$ & $\begin{array}{l}\text { \{Total kejadian } \\
\text { terjadi } \\
\text { bersamaan/Antecen } \\
\operatorname{dent}(\mathrm{X})\}=\{2 / 2=1)\end{array}$ & $\begin{array}{l}\text { \{Total data } \\
\text { /Consequent } \\
(\mathrm{Y})\}=\{12 / 2=6\}\end{array}$ \\
\hline
\end{tabular}

Aturan yang terbentuk berdasarkan perhitungan dengan menggunakan sampel data adalah sebagai berikut: Jika waktu perbaikan lama dan kerusakan terdapat pada hydraulic maka tingkat resikonya rendah dengan nilai support (dominasi) $40 \%$ dan nilai confidence 
(tingkat kepercayaan) 1 atau 100\%. Nilai support menggambarkan nilai dominasi terjadinya aturan tersebut, sedangkan nilai confidence menyatakan seberapa besar persentase kejadian tersebut akan terjadi atau biasa dikatakan dengan tingkat kepercayaan dan nilai lift menggambarkan kekuatan aturan yang terjadi. Jika lift ratio kurang dari 1 maka aturan yang terjadi lemah, sedangkan jika lebih dari 1 maka aturan terjadinya kuat, namun jika nilainya $=1$, maka tidak berkorelasi.

Berikutnya dilakukan pengolahan data dengan menggunakan seluruh data kerusakan menggunakan software $\mathrm{R}$ untuk menemukan pola kerusakan yang terjadi pada data breakdown berdasarkan metode association rules algoritma apriori. Berikut ini adalah pola data yang terbentuk.

1. Kerusakan dengan perbaikan yang singkat dan tingkat risiko tinggi memiliki nilai support $=0,013$, confidence $=1$ dan lift $=7,30$

2. Kerusakan jenis hydraulic dengan tingkat risiko sedang memiliki nilai support $=0,019$, confidence $=1$ dan lift $=1.71$

3. Kerusakan pada shift 1 dengan jenis kerusakan hydraulic dan tingkat risiko sedang memiliki nilai support $=0,016$, confidence $=1$ dan lift $=1.71$

4. Kerusakan dengan lama perbaikan singkat dan jenis kerusakan hydraulic dan tingkat risiko sedang, memiliki nilai support $=0,019$, confidence $=1$ dan lift $=1,71$

5. Kerusakan yang terjadi pada shift 3 dengan lama perbaikan sedang dan tingkat risiko tinggi, memiliki nilai support $=0,032$, confidence $=0,91$ dan lift $=6,64$

6. Kerusakan yang terjadi pada shift 1 dengan lama perbaikan singkat dengan jenis kerusakan hydraulic dan tingkat risiko sedang, memiliki nilai support $=0,015$, confidence $=1$ dan lift $=1,71$

7. Kerusakan yang terjadi pada shift 2 dengan lama perbaikan sedang dan jenis kerusakan mekanik dan tingkat risiko tinggi, memiliki nilai support $=0,012$, confidence $=1$ dan lift $=7,30$

Untuk memperjelas ketujuh pola diatas, berikut ini adalah gambar hasil association rules yang terbentuk berdasarkan pengolahan data kerusakan mesin di PT Z.

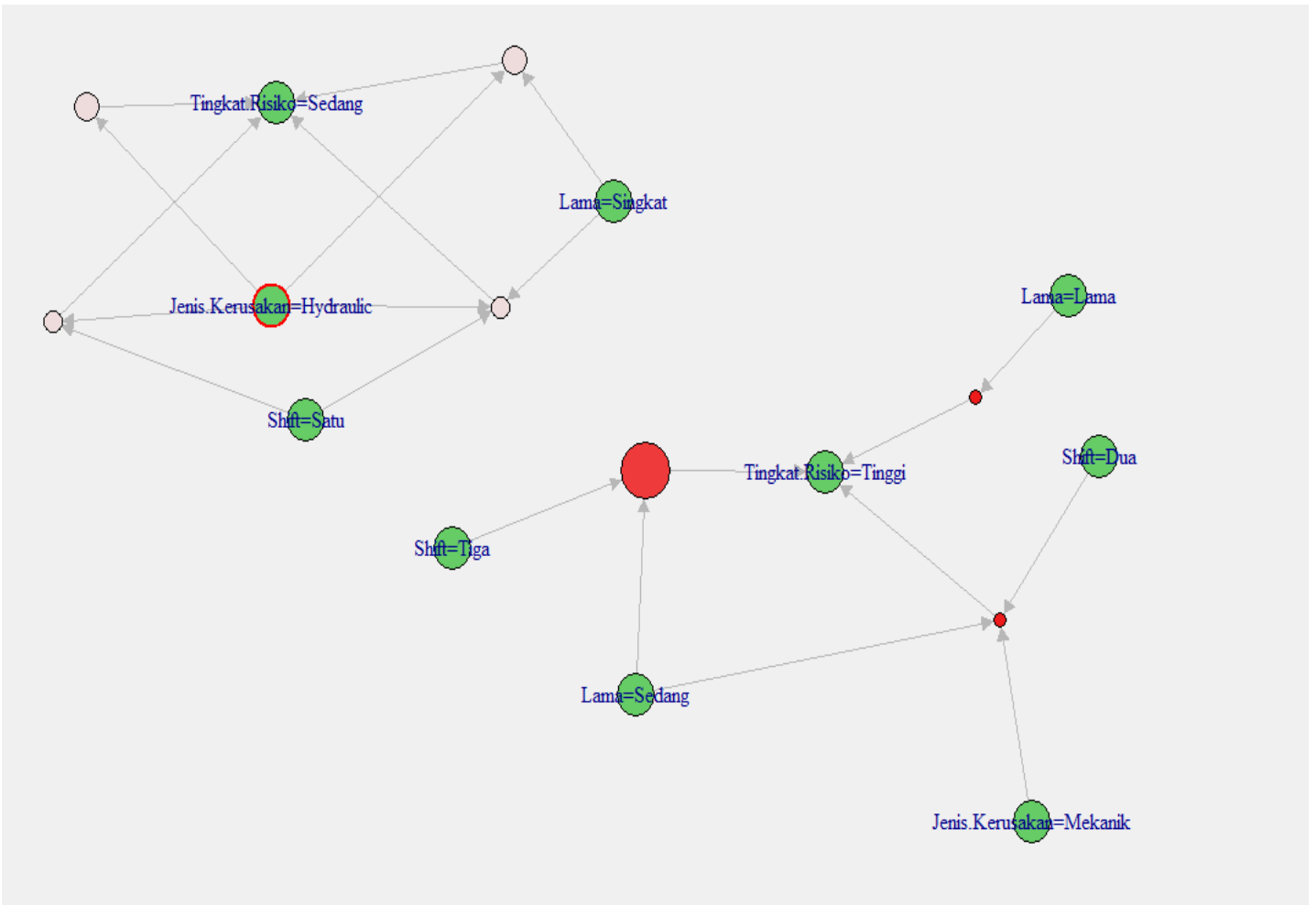

Gambar 1. Pola Data Kerusakan Berdasarkan Association Rules 
adalah:

Hasil pengolahan data memperoleh 11 aturan asosiasi yang terbentuk, diantaranya

Aturan 1 : Waktu perbaikan kerusakan relatif singkat untuk resiko kerusakan yang Tinggi.

Aturan 2 : Untuk jenis kerusakan hydraulic maka biasanya tingkat resiko yang ditimbulkan adalah sedang.

Aturan 3 : Untuk kerusakan yang terjadi pada shift satu serta jenis kerusakan hydraulic maka tingkat resikonya adalah sedang.

Aturan 4 : Untuk kerusakan yang lama perbaikannya singkat, jenis kerusakan yang terjadi adalah hydraulic dengan tingkat resiko adalah sedang.

Aturan 5 : Untuk kerusakan yang terjadi kerusakan pada shift tiga, lama perbaikan sedang dan biasanya tingkat resikonya adalah tinggi.

Aturan 6 : Untuk kerusakan yang terjadi pada shift satu, serta membutuhkan perbaikan kerusakan yang relatif singkat, dengan jenis kerusakannya adalah hydraulic, maka biasanya tingkat resiko yang ditimbulkan adalah sedang.

Aturan 7 : Untuk kerusakan yang terjadi pada shift dua, waktu yang dibutuhkan untuk perbaikan kerusakan adalah sedang, dan biasanya jenis kerusakannya adalah mekanik dengan tingkat resiko yang ditimbulkan adalah tinggi.

Pada Gambar 1 juga terlihat bahwa untuk pola shift tiga, lama perbaikan yang sedang dan tingkat resiko yang tinggi, memiliki peluang kejadian yang lebih tinggi jika dibandingkan dengan yang lainnya, karena lingkaran yang terbentuk lebih besar. Berikutnya, jenis kerusakan mekanik, shift dua, waktu perbaikan yang lama dan sedang, serta tingkat resiko yang tinggi memiliki aturan yang kuat, yang dimaksud dengan aturan yang kuat adalah pola tersebut pasti terjadi.

Berdasarkan data kerusakan mesin yang diperoleh, diketahui bahwa antara bulan Januari 2018 sampai dengan tanggal 13 Agustus 2018 terjadi kerusakan sebanyak 314 data dengan lama kerusakan 10570 menit atau 176.17 jam yang telah melebihi KPI untuk Divisi Maintenance yaitu pencapaian target penurunan waktu kerusakan sebesar 108 jam. Sesuai dengan konsep perawatan mesin yang berlaku, sampai dengan umur pakai mesin tertentu, terjadinya kerusakan umumnya akan terus meningkat.

Data kerusakan pada tabel 5 berikut ini adalah data kerusakan terkait. Terlihat bahwa kejadian kerusakan durasi yang tinggi serta memiliki peluang kejadian yang lebih tinggi jika dibandingkan kejadian kerusakan yang lain memiliki potensi yang besar bagi Divisi Maintenance untuk mencapai target KPI nya.

Tabel 5. Data Kerusakan Shift 3 dengan Durasi Sedang dan Tinggi dan Tingkat Risiko Tinggi

\begin{tabular}{cccc}
\hline Tanggal & Kerusakan & Durasi & Jenis Kerusakan \\
\hline 12-Jan-2018 & As auto conveyor, patah & 600 & Mekanik \\
20-Feb-2018 & Kontaktor mould bawah, putus & 60 & Listrik \\
27-Feb-2018 & Cylinder dispenser tidak bisa main 38 & 90 & Listrik \\
22-Mar-2018 & mc 22 motor nya error & 90 & motor \\
5-Apr-2018 & Mc.24 trip terus/start & 60 & Listrik \\
9-Apr-2018 & Mesin nomer 3 tidak bisa di start & 60 & Listrik \\
12-Apr-2018 & Motor pompa mati & 60 & Listrik \\
20-Apr-2018 & Motor mesin mati & 60 & Mekanik \\
21-Apr-2018 & Stacker grid error & 60 & Pneumatik \\
13-Jul-2018 & Temperatur POT turun & 60 & Pneumatik \\
\hline
\end{tabular}

Dengan mempertimbangkan hasil analisis pola data diketahui bahwa untuk kerusakan yang terjadi pada shift tiga dengan lama perbaikan yang sedang serta memiliki tingkat resiko yang tinggi memiliki peluang kejadian yang lebih tinggi jika dibandingkan 
dengan yang lainnya, sebaiknya perusahaan memastikan ketersediaan staf serta suku cadang terkait untuk kebutuhan perbaikan mesin pada shift 3 supaya dapat meminimasi durasi perbaikan mesin.

Hasil analisis berdasarkan association rules berikutnya terkait pola data adalah bahwa kerusakan dengan jenis kerusakan mekanik yang terjadi pada shift dua dengan kategori waktu perbaikan yang lama dan sedang, serta tingkat resiko yang tinggi memiliki aturan yang kuat. Data kerusakan pada tabel 6 menunjukkan bahwa kejadian kerusakan menyebabkan durasi perbaikan kerusakan yang relatif lama $(30$ - 90 menit). Dengan mengetahui adanya hubungan yang kuat antara shift terjadinya kerusakan pada shift 2 dengan jenis kerusakan mekanik, pihak perusahaan sebaiknya menyediakan kebutuhan sumber daya untuk perbaikan mekanik yang cukup (staf dan peralatan) pada shift 2 supaya aksi perbaikan kerusakan dapat segera dilakukan oleh Staf Mekanik.

\begin{tabular}{ccc} 
Tabel 6. Data Kerusakan Mekanik pada Shift 2 dengan Durasi Sedang dan Ting \\
& Wan Tingkat Risiko Tinggi & \\
\hline Tanggal & What? & Durasi \\
\hline 23-Jan-2018 35 kabel motor pump korsleting & 40 \\
13-Feb-2018 & Mc 25 belt panjang, putus & 30 \\
23-Mar-2018 & Mc 27 belt pendek, putus & 20 \\
5-Apr-2018 & Mesin tidak mau jalan & 40 \\
10-Apr-2018 & Mc. 44 gear belt panjang abnormal & 45 \\
10-Apr-2018 & Mc. 20 dudukan baut pendorong mold lepas & 15 \\
16-Apr-2018 & Belt panjang mc.47, putus & 30 \\
17-Apr-2018 & As belt pendek mc. 31, patah & 30 \\
23-Apr-2018 & Temperatur POT, turun & 60 \\
5-May-2018 & Belt panjang, putus & 25 \\
9-May-2018 & Baut peluncur mold, lepas & 30 \\
11-May-2018 & Belt pendek sobek & 20 \\
30-May-2018 & Rantai Trim dies, putus & 30 \\
28-Jun-2018 & As roll belt pendek, patah & 60 \\
4-Jun-2018 & Belt pendek robek & 30 \\
25-Jun-2018 & Air limbah tidak terbuang & 30 \\
5-Jul-2018 & Belt panjang, putus & 20 \\
9-Jul-2018 & Belt panjang, putus & 30 \\
17-Jul-2018 & Belt panjang, putus & 30 \\
30-Jul-2018 & As belt pendek, patah & 30 \\
6-Aug-2018 & Belt panjang, putus & 30 \\
6-Aug-2018 & Baut sliding mold, lepas & 30 \\
18-Aug-2018 & As trim dies goyang & 30 \\
20-Aug-2018 & V Belt panjang putus &
\end{tabular}

\section{KESIMPULAN}

Terjadi kejadian breakdown sebanyak 314 data dengan lama kerusakan 10,570 menit atau 176.17 jam yang telah melebihi KPI untuk Divisi Maintenance PT Z. Hasil pemetaan data gangguan kerusakan mesin produksi menunjukkan bahwa jenis kerusakan yang paling sering terjadi adalah kerusakan mekanik dan didominasi dengan kerusakan dengan tingkat resiko sedang, serta kebanyakan terjadi pada shift 1 dan shift 3.

Berdasarkan pola data yang terbentuk hasil pengolahan data association rules diketahui adanya hubungan yang kuat antara kerusakan yang terjadi pada shift 2 dengan jenis kerusakan mekanik, juga bahwa kerusakan yang terjadi pada shift tiga dengan lama perbaikan yang sedang serta memiliki tingkat resiko yang tinggi memiliki peluang kejadian yang lebih tinggi jika dibandingkan dengan yang lainnya, pihak perusahaan sebaiknya Hasil analisis menunjukkan bahwa terdapat hubungan yang kuat antara kerusakan pada shift 2 untuk jenis kerusakan mekanik, serta kerusakan pada shift tiga dengan lama 
perbaikan sedang dan tingkat resiko yang tinggi memiliki peluang kejadian yang lebih tinggi jika dibandingkan kejadian lainnya.

Perusahaan sebaiknya menyediakan kebutuhan staf mekanik, peralatan dan suku cadang yang memadai pada shift 2 dan shift 3 sehingga dapat meminimasi durasi perbaikan mesin serta mengefektifkan pelaksanaan pendekatan Total Productive Maintenance (TPM) dapat mencapai target KPI nya.

\section{DAFTAR PUSTAKA}

[1]. Marie IA, D K Sari, P Astuti and M Teorema. 2017. Design of Disturbances Control Model at Automotive Company IOP Conf. Series: Materials Science and Engineering 277 (2017) 012020.

[2]. Putra, Muhammad Aditya dan Iveline Anne Marie. 2015. Rancangan Perawatan Bus Transjakarta Menggunakan Pendekatan Reliability Centered Maintenance Di Perum Damri SBU Busway Koridor I \& VIII. Jurnal Ilmiah Teknik Industri Vol. 3 No. 3, 208219.

[3]. Kuswardani D, Widyanto MR, Trihandini I. 2011. Metode Association Rules untuk Analisis Citra CT Organ Pasien Kanker Ovarium. Kursor 62 111-20.

[4]. Hakim L, Fauzy A. 2015. Penentuan Pola Hubungan Kecelakaan Lalu Lintas Menggunakan Metode Association Rules dengan Algoritma Apriori. The 1st University Research Colloquium (URECOL).

[5]. J. Santoni. 2012. Implementasi Data Mining Dengan Metode Market Basket Analysis. Teknologi Informasi dan Pendidikan Vol.5 p.2.

[6]. Fadlina. 2014. Data Mining untuk Analisa Tingkat Kejahatan Jalanan dengan Algoritma Association Rules Metode Apriori. Informasi dan Teknologi Ilmiah (INTI) 31 144-54.

[7]. Zhao Y, Cen Y. 2013. Data Mining Applications with R. Waltham: Elsevier.

[8]. Siregar SR. 2014. Implementasi Data Mining Pada Penjualan Tiket Pesawat Menggunakan Algoritma Apriori. Pelita Informatika Budi Dharma 7 1 152-6. 